\title{
EFFECT OF PROHEXADIONE-CALCIUM ON NECTAR COMPOSITION OF POMACEOUS FLOWERS AND ON BACTERIAL GROWTH
}

\author{
F. SPINELLI ${ }^{1}$, J.L. VANNESTE ${ }^{2}$, G.L. MARCAZZAN ${ }^{3}$, \\ A.G. SABATINI ${ }^{3}$ and G. COSTA ${ }^{1}$ \\ ${ }^{1}$ Dipartimento di Colture Arboree, Università di Bologna, Italy \\ ${ }^{2}$ HortResearch, Ruakura Research Centre, Private Bag 3123, Hamilton, \\ New Zealand \\ ${ }^{3}$ Istituto Nazionale d'Apicoltura, Bologna, Italy \\ Corresponding author: JVanneste@hortresearch.co.nz.
}

\begin{abstract}
Prohexadione-calcium is an acylcyclohexanedione that reduces incidence of fire blight, caused by Erwinia amylovora. To determine whether prohexadione-calcium can be used in conjunction with biological control agents, its effect on the secretion and composition of nectar from apple and pear flowers was evaluated. Plants treated with prohexadione-calcium produced more nectar, but the sugar concentration of the nectar was lower. The ability of E. amylovora, and of two biological control agents of fire blight, Pantoea agglomerans and Pseudomonas fluorescens, to grow in a sugar solution corresponding to the composition of nectar from treated or untreated plants was determined in the laboratory. All bacteria including E. amylovora grew better in the sugar solution corresponding to the nectar from treated plants. The concentration of sugar in the non-treated flowers may be too high for bacterial growth. These results also suggest that prohexadione-calcium can be used alongside biological control agents for reduction of fire blight incidence.

Keywords: fire blight, biological control, Pantoea agglomerans, Pseudomonas fluorescens, acylcyclohexanediones.
\end{abstract}

\section{INTRODUCTION}

Growth-regulating acylcyclohexanediones, such as prohexadione-calcium (calcium 3-oxido-4-propionyl-5-oxo-cyclohexene carboxylate; ProCa) and trinexapac-ethyl [4-(1'-cyclopropyl $\{1$ '-hydroxy $\}$ methylene)-3,5-dioxocyclohexane-1-carboxylate; TrixE] represent an alternative to antibiotics or heavy metal for the control of fire blight (Spinelli et al. 2005). ProCa and TrixE are structurally similar to 2-oxoglutaric acid and consequently they block 2-oxoglutarate-dependent dioxygenases, which are involved in the formation of growth-active gibberellins and in the metabolism of flavonoids (Rademacher 2000).

Although ProCa does not have any antimicrobial activity, its protective effect against fire blight infection on shoots has been previously reported (Costa et al. 2001; Bazzi et al. 2003). However, its effect against flower infection, which is a key step in the fire blight epidemiology (Thomson 2000), has not been fully investigated. Preliminary data suggest that ProCa and TrixE reduce fire blight incidence on apple and pear flowers (F. Spinelli, unpubl. data). Therefore, these compounds could also be used in conjunction with biological control agents, such as Pantoea agglomerans and Pseudomonas fluorescens.

Since Erwinia amylovora, the fire blight pathogen, gets into the plant through the nectarthodes (Wilson et al. 1990), the nectar composition may play an important role in the infection process. Under a certain threshold concentration, the sugars present in 
the nectar may be a valuable source of energy for the bacteria (Wilson et al. 1989), thus facilitating the infection (Thomson 1986; Wilson et al. 1990; Campbell et al. 1991). On the other hand, a sugar concentration that is too high may inhibit bacterial growth (Billing 1976; Smith 1990; Smith 1996; Steiner 1990; Thomson et al. 1982; Pusey 1999). Therefore, variation in the sugar concentration of the nectar may influence the epiphytic population of the pathogen and the biological control agents. Variations in the ability of these different bacteria to grow in the nectar could translate into different levels of infection or control. This is why this project aimed at determining the effect of ProCa on nectar secretion and sugar composition, and subsequent effects on bacterial growth in vitro.

\section{Plant material and nectar collection}

\section{MATERIALS AND METHODS}

Apple plants (cv. Golden delicious) and pear plants (cv. Abbé fetèl) at the pink button stage, were sprayed until run-off with $250 \mathrm{ppm}$ of ProCa. Plants treated with water were used as a control. For each treatment, 3 blocks of 8 trees each were sprayed. After 15 days, the nectar was collected from the nectaries using a glass pipette especially designed for nectar sampling (Fig. 1).

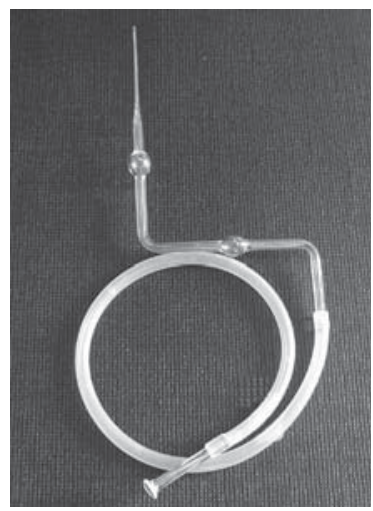

FIGURE 1: Pipette used for collecting nectar. The design helps to minimise the dilution of nectar with humidity present in human breath.

The nectar was collected on two consecutive days with similar weather conditions; during sampling the temperature varied between $18^{\circ} \mathrm{C}$ and $22^{\circ} \mathrm{C}$, and the humidity varied between 60 and $70 \%$. To minimise the possible differences due to differential secretion of nectar during the day, nectar was collected from control and treated plants at the same time. Daily production of nectar, total sugar concentration, ratio between sugars and dry matter were determined with a refractometer and by gas chromatography (Bagdanov et al. 1997).

\section{Nectar composition analysis}

A $100 \mu \mathrm{l}$ aliquot of nectar of was added to $4 \mathrm{ml}$ of distilled water and mixed with $40 \mu \mathrm{l}$ of a $10 \%$ mannitol solution (internal standard from Fluka). One hundred $\mu \mathrm{l}$ of the solution was transferred to a conical-bottomed test tube and dried out in a current of nitrogen at $50^{\circ} \mathrm{C}$. Once dried, $200 \mu \mathrm{l}$ of oxime reagent (pyridine solution containing $12 \mathrm{mg} / \mathrm{ml}$ hydroxylamine hydrochloride) were added and the tube sealed with a screw-on cap. After mixing, the tube was heated at $70-75^{\circ} \mathrm{C}$ for $30 \mathrm{~min}$. When the sample cooled to room temperature, $100 \mu \mathrm{l}$ of hexamethyldisilazane and $10 \mu \mathrm{l}$ of trifluoroacetic acid were added, the tubes were then well-mixed and left to stand for $30 \mathrm{~min}$. The sample 
was then centrifuged at $5000 \mathrm{rpm}$ for 2-3 sec. For analysis by gas chromatography, $0.6-1 \mu \mathrm{l}$ of the supernatant were used. The gas chromatograph was fitted with an SE 52 capillary column and a flame ionisation detector. The fused silica gel capillary column was $25 \mathrm{~m}, 0.32 \mathrm{~mm}$ diameter, $0.1-0.15 \mu \mathrm{m}$ film thickness. A carrier gas flow of $4 \mathrm{ml} / \mathrm{min}$ of hydrogen was used.

Effect of nectar sugar composition on bacterial growth

The growth of E. amylovora EaDCA 289/01(Spinelli 2002), two strains of P. agglomerans, P10c (Vanneste et al. 2002) and EhDCA 296/01 (Spinelli 2002), and P. fluorescens: PfA506 (Lindow 1982) was tested in the laboratory. The amounts of sucrose, glucose and fructose necessary to obtain the same percentages as those found in the nectar of apple or pear flowers treated or not with ProCa were dissolved in phosphate buffer $50 \mathrm{mM} \mathrm{pH} \mathrm{7.3.} \mathrm{These} \mathrm{solutions,} \mathrm{called} \mathrm{artificial} \mathrm{nectar,} \mathrm{were} \mathrm{sterilised}$ by filtration through a $0.22 \mu \mathrm{m}$ membrane. Each bacterial strain was grown in $30 \mathrm{ml}$ glass vials containing $5 \mathrm{ml}$ artificial nectar; $10 \mu \mathrm{l}$ of an overnight culture in Luria broth was used to inoculate the artificial nectar. The bacterial cultures were incubated for 5 days at $27^{\circ} \mathrm{C}$ with moderate shaking. The bacterial populations were assessed at $0,4,24,48$ and $72 \mathrm{~h}$ after inoculation by tenfold sequential dilutions and plating on appropriate medium agar plates. The experiment was repeated 4 times.

\section{RESULTS \\ Effect of ProCa on the quantity and composition of apple and pear nectar}

Apple and pear nectars were mainly composed of sucrose, fructose and glucose (Table 1). However, the relative ratios of these sugars differed between the two plant species. Pear nectar was much less concentrated than apple nectar (Table 1). Nectar from apple and pear flowers treated with the acylcyclohexanediones contained significantly less sugar than the nectar from the control plants. In addition, ProCa treatment enhanced the production of nectar per flower (Table 1).

TABLE 1: Glucose, fructose, sucrose and total sugar as a percentage of the total weight of nectar collected from apple or pear flowers treated or not treated with Pro-Ca and the number of flowers needed to collect 100 $\mu l$ of nectar.

\begin{tabular}{lcccrc}
\hline Source of nectar & Fructose & Glucose & Sucrose & Total sugar & $\begin{array}{c}\text { No. } \\
\text { flowers }\end{array}$ \\
\hline Pear - not treated & $7.73 \mathrm{a}^{1}$ & $8.64 \mathrm{a}$ & $1.01 \mathrm{a}$ & $17.56 \mathrm{a}$ & $273 \mathrm{a}$ \\
Pear treated with Pro-Ca & $5.88 \mathrm{a}$ & $6.63 \mathrm{~b}$ & $0.84 \mathrm{a}$ & $13.35 \mathrm{~b}$ & $197 \mathrm{~b}$ \\
& & & & & \\
Apple - not treated & $9.26 \mathrm{a}$ & $9.58 \mathrm{a}$ & $30.90 \mathrm{a}$ & $50.34 \mathrm{a}$ & $442 \mathrm{a}$ \\
Apple treated with Pro-Ca & $6.38 \mathrm{~b}$ & $6.68 \mathrm{~b}$ & $27.06 \mathrm{~b}$ & $40.12 \mathrm{~b}$ & $331 \mathrm{~b}$ \\
\hline
\end{tabular}

${ }^{1}$ Percentages or numbers for either apple or pear nectar followed by the same letter were not significantly different. Means separation by Duncan's test $(\mathrm{P}<0.05)$.

\section{Effect of sugar concentration on bacterial growth}

The concentration of E. amylovora and the three biological control agents grown in the four artificial nectars are presented in Figure 2. Erwinia amylovora EaDCA 289/01 was less sensitive than the other strains to the sugar concentration present in the artificial nectars, while $P$. fluorescens PfA506 was the most affected by the variation in sugar concentration. When grown in artificial nectar corresponding to nectar from untreated apple flowers, the concentration of the three biological control agents decreased rapidly, and they were not detectable $24 \mathrm{~h}$ after inoculation. In artificial nectar corresponding to nectar from apple flowers treated with Pro-Ca, P. agglomerans (EhDCA 269/01 and P10c) populations grew up to ca $10^{5} \mathrm{cfu} / \mathrm{ml}$ after $72 \mathrm{~h}$. In the same artificial nectar the population of P. fluorescens PfA506 decreased rapidly and was not detectable $24 \mathrm{~h}$ after inoculation. 

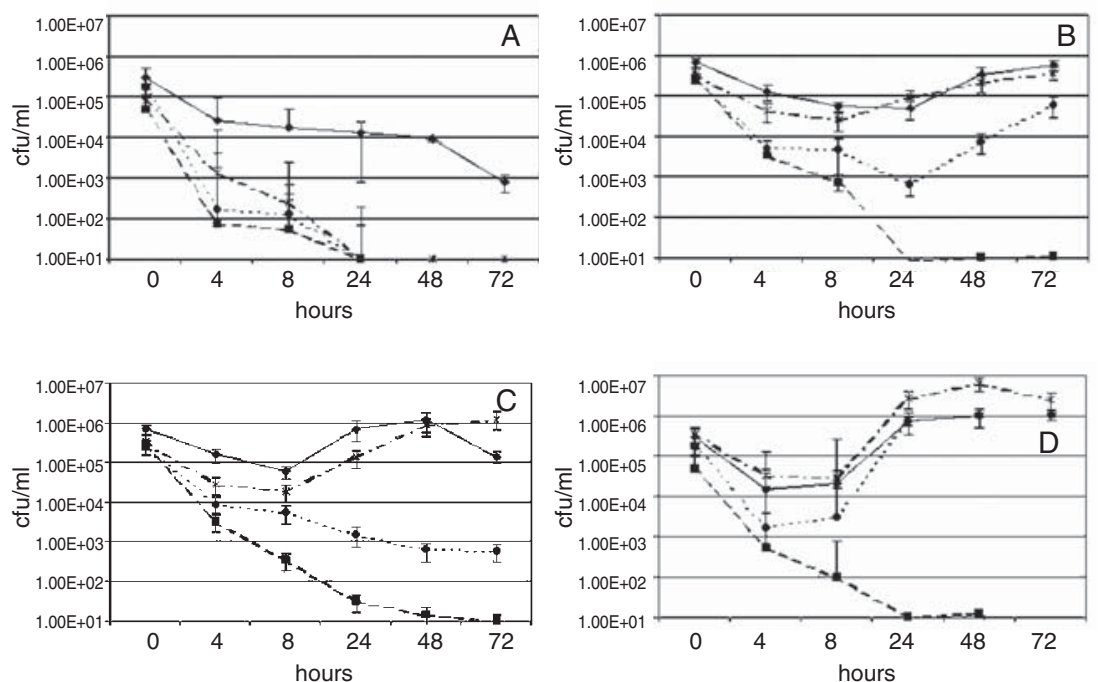

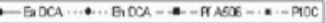

FIGURE 2: Population concentration (cfu/ml) of E. amylovora EaDCA289/01, P. agglomerans EhDCA269/01 and P10c, and P. fluorescens A506 grown in phosphate buffer containing sugar corresponding to (a) nectar from non treated apple flowers, (b) ProCa-treated apple flowers, (c) non treated pear flowers and (d) ProCa-treated pear flowers. Vertical bars represent the standard error of the means.

The sugar concentration in the pear nectar was less than that in the apple nectar, and therefore, its effect on bacterial growth was not as pronounced as that of apple nectar. Nevertheless, the artificial nectar corresponding to nectar from ProCa-treated pear flowers supported a higher bacterial population than the nectar corresponding to nectar from untreated pear flowers. In ProCa-treated pear nectar, P. agglomerans EhDCA 269/01 and P10C multiplied rapidly, whereas $P$. agglomerans EhDCA 269/01 seemed to only just survive in untreated pear artificial nectar. As with apples, P. fluorescens PfA506 was not detected in either of the two artificial pear nectars after 72 h. Erwinia amylovora EaDCA 289/01 could multiply on artificial pear nectar representing nectar from treated or untreated plants.

\section{DISCUSSION}

The lower sugar concentration in the nectar and greater amounts of nectar collected from flowers treated with ProCa might be due to a dilution effect as a consequence of a higher availability of water, possibly due to a greater root extension. In fact, after treatment with acylcyclohexanediones, plant assimilates are generally shifted into the roots, which are then stimulated to grow (Fletcher \& Arnold 1986; Guak et al. 2001). Acylcyclohexanediones can also decrease the nectar sugar concentration by inhibiting the gibberellins and ethylene biosynthesis. After application of gibberellin (1500 ppm) to Cucumis sativus flowers, Kamler \& Tronickova $(1980,1982)$ observed an increase in the sugar content of the nectar. In addition, ethylene promotes mobilization of substrates and an efflux of material from petals to the gynaecium, nectar and stem 
(Nichols \& Ho 1975). Nichols \& Ho (1975) observed that the levels of ethylene that caused irreversible wilting of petals also promoted an accelerated transfer of sucrose to the nectar. Therefore, it is likely that the application of acylcyclohexanediones reduced both ethylene and gibberellins level in plant tissues, and consequently decreased the sugar content of the nectar.

The nectar from ProCa treated flowers had a lower osmotic potential than nectar from control flowers due to a lower concentration of sugar. Therefore, nectar from treated flowers was more suitable for bacterial growth. Erwinia amylovora was less affected by sugar concentration than the other bacterial strains. It has been suggested that E. amylovora could use the sucrose present in the nectar for the synthesis of levan, which is a polymer of fructose ( $\beta-2,6$-fructan). Levan synthesis would result in a reduction of the osmotic potential such that it became suitable for the growth of E. amylovora (Gross et al. 1992). In the artificial nectar corresponding to untreated apple or pear flowers nectar, the population of two of the three strains of biological control agents rapidly decreased below level of detection; P. agglomerans P10c could multiply on artificial nectar from untreated pear flowers. In contrast, in artificial nectar corresponding to nectar from ProCa-treated apple or pear flowers, the strains of P. agglomerans, and in particular P10c, were able to multiply to relatively high levels. This suggests that potential biological control agents may be able to colonise the nectarial cup of plants treated with ProCa, and potentially with other acylcyclohexanediones, and therefore increase the level of control of fire blight.

Further studies are needed to determine whether the effect observed in vitro on bacterial growth also occurs in vivo and to investigate the physiological mechanisms underlying the reduction of sugar concentration.

\section{REFERENCES}

Bagdanov S, Martin P, Luellmann C 1997. Harmonised methods of the European Honey Commission. In: Determination of sugar by GC. Apidologie Extra issue. Pp. 1-59.

Bazzi C, Messina C, Tortoreto L, Stefani E, Bini F, Brunelli A, Andreotti C, Sabatini E, Spinelli F, Costa G, Hauptmann S, Stammler G, Doerr S, Marr J, Rademacher W 2003. Control of pathogen incidence in pome fruits and other horticultural crop plants with prohexadione-Ca. European Journal of Horticultural Science 68: 108-104.

Billing E 1976. Weather and fire blight in England. Annals of Applied Biology 82: 259-266.

Campbell RJ, Fell RD, Marini RP 1991. Canopy position, defoliation and girdling influence apple nectar production. HortScience 26: 531-532.

Costa G, Andreotti C, Bucchi F, Sabatini E, Bazzi C, Malaguti S, Rademacher W 2001. Prohexadione-Ca (Apogee ${ }^{\circledR}$ ): growth regulation and reduced fire blight incidence in pear. HortScience 36: 931-933.

Fletcher RA, Arnold V 1986. Stimulation of cytokinins and chlorophyll synthesis in cucumber cotyledons by triadimefon. Physiologica Plantarum 66: 197-201.

Gross M, Geier G, Rudolph K, Geider K 1992. Levan and levasucrase synthetised by the fire blight pathogen Erwinia amylovora. Physiological Molecular Plant Patholology 40: 371-381.

Guak S, Neilsen D, Looney NE 2001. Growth, allocation of N and carbohydrates, and stomatal conductance of greenhouse grown apple treated with prohexadione-Ca and gibberellins. Journal of Horticultural Science and Biotechnology 76: 746-752.

Kamler F, Tronickova E 1980. Nectar production by pickling cucumber genotypes with different types of flowering. Sbornik-UVTIZ,-Zahradnictvi. 1980, 7: 2, 117-126 (Abstr.).

Kamler F, Tronickova E 1982. Nectar production of different genotypes of cucumber, Cucumis sativus. Zapylanie roslin warzywnych. III Seminarium, 28 II - 1 III 1979. 1982, 113-134 (Abstr.). 
Lindow SE 1982. Integrated control of frost injury and fire blight of pear with antagonistic epiphytic bacteria. Phytopathology 72: 946.

Nichols R, Ho LC 1975. An effect of ethylene on the distribution of 14C-sucrose from the petals to other flower parts in the senescent cut inflorescence of Dianthus caryophyllus. Annals of Botany 39: 433-438.

Pusey PL 1999. Effect of nectar on microbial antagonists evaluated for use in control of fire blight of pome fruits. Phytopathology 89: 39-46.

Rademacher W 2000. Growth retardants: Effects on gibberellin biosynthesis and other metabolic pathways. Annual Review of Plant Physiology and Plant Molecular Biology 51: 501-531.

Smith TJ 1990. Frontiers in fire blight management. Good Fruit Grower 41: 16-18.

Smith TJ 1996. A risk assessment model for fire blight of apple and pear. Acta Horticulturae 411: 97-104.

Spinelli F 2002. Changes in plant metabolism induced by dioxygenase inhibitors and their effect on the epiphytic microbial community and fire blight (Erwinia amylovora) control. PhD thesis, University of Bologna, Bologna, Italy.

Spinelli F, Speakman JB, Rademacher W, Halbwirth H, Stich K, Costa G 2005. Luteoforol, a flavan 4-ol, is induced in pome fruits by prohexadione-Ca and shows phytoalexin-like properties against Erwinia amylovora and other plant pathogens. European Journal of Plant Pathology 111:1-10

Steiner PW 1990. Predicting apple blossom infections by Erwinia amylovora. Microbiology 143: 625-632.

Thomson SV 1986. The role of the stigma in fire blight infections. Phytopathology 76: 476-482.

Thomson SV 2000. Epidemiology of fire blight. In: Vanneste J.L. ed. Fire blight The Disease and its Causative Agent, Erwinia amylovora. CABI Publishing, Wallingford, United Kingdom. Pp. 9-37.

Thomson SV, Schroth MN, Moller WJ, Reil WO 1982. A forecasting model for fire blight of pear. Plant Disease 66: 576-579.

Vanneste JL, Cornish DC, Yu J, Voyle MD 2002. P10c: a new biological control agent for control of fire blight which can be sprayed or distributed using honey bees. Acta Horticulturae 590: 231-235.

Wilson M, Epton HAS, Sigee DC 1989. Erwinia amylovora infection of hawthorn blossom: II. The stigma. Journal of Phytopathology 127: 15-28.

Wilson M, Epton HAS, Sigee DC 1990. Erwinia amylovora infection of hawthorn blossom: III. The nectary. Journal of Phytopathology 187: 62-74. 